https://helda.helsinki.fi

\title{
Geoeconomics in the context of restive regional powers
}

\section{Mattlin, Mikael}

2016-06

Mattlin , M \& Wigell , M 2016 , ' Geoeconomics in the context of restive regional powers ', Asia Europe Journal , vol. 14 , no. 2 , pp. 125-134 . https://doi.org/10.1007/s10308-015-0443-9

http://hdl.handle.net/10138/240776

https://doi.org/10.1007/s10308-015-0443-9

acceptedVersion

Downloaded from Helda, University of Helsinki institutional repository.

This is an electronic reprint of the original article.

This reprint may differ from the original in pagination and typographic detail.

Please cite the original version. 
Mattlin, Mikael and Mikael Wigell (2016) "Geoeconomics in the context of restive regional powers," Asia Europe Journal, 14 (2): 125-134 (https://doi.org/10.1007/s10308-015-0443-9)

(C) Springer-Verlag Berlin Heidelberg 2015.

\section{Geoeconomics in the context of restive regional powers}

\section{- ABSTRACT -}

Geoeconomic power and its use appear to be a crucial, albeit understudied aspect of today's international relations. Traditionally, international power has been thought of in geopolitical rather than geoeconomic terms. Indeed, ever since the famous debate about sea power and land power between Alfred Thayer Mahan and Halford MacKinder at the cusp of the $20^{\text {th }}$ century, scholars have linked geography with the pursuit of political and military power. However, the term "geoeconomics" is of a more recent origin, and also more vexing than geopolitics. The term is commonly associated with Edward Luttwak's writings in the early 1990s (Luttwak 1990, 1993), although it did not spurn a major scholarly discussion at the time. For Luttwak, geoeconomics denoted the successor system of interstate rivalry that emerged in the aftermath of Cold War geopolitics. As a consequence of the rise of major new economic powers, such as China, India and Brazil, there is renewed interest in the concept. Yet, an overview of the literature indicates that there seems to be no agreement on what exactly the term denotes. This special issue tackles the different ways in which the term geoeconomics is used, in the context of the policies pursued by major regional powers (e.g. China, Russia and Germany). How are we to understand the actions of these regional powers in contexts where economic interests, political power and geography intersect? In the introductory article, we overview the literature and summarise the main arguments of the individual papers.

Geoeconomic power and its use appear to be a crucial, albeit understudied aspect of today's international relations. Traditionally, international power has been thought of in geopolitical rather than geoeconomic terms. Indeed, ever since the famous debate about sea power and land power between Alfred Thayer Mahan and Halford MacKinder in late $19^{\text {th }}$ and early $20^{\text {th }}$ century, scholars have linked geography and the pursuit of political and military power together (Mahan 1890; MacKinder 1904; Cosgrove 2008: 189-193). Yet, the notion of economic power was present already in the writings of Mahan and MacKinder. MacKinder was obsessed with the perennial competition between Europe and Asia for control over the Eurasian landmass. In this context, he also debated the significance and benefits of railway networks bringing factory produce across Eurasia, as opposed to sending goods by ship (MacKinder 1904: 434). Mahan, as Tara Murphy has pointed out, 
drew attention to the "power projection capabilities a state could reap by dominating seaborne commerce" (Murphy 2010: 31).

Nevertheless, the actual term "geoeconomics" is of a more recent origin, and also more vexing than geopolitics. The term is commonly associated with Edward Luttwak's writings in the early 1990s (Luttwak 1990, 1993), although it did not spurn a major scholarly discussion at the time. Writing at the cusp of the end of the Cold War, Luttwak contended "Everyone, it appears, now agrees that the methods of commerce are displacing military methods-with disposable capital in lieu of firepower, civilian innovation in lieu of military-technical advancement, and market penetration in lieu of garrisons and bases" (1990: 17). For Luttwak, geoeconomics denoted the successor system of interstate rivalry that emerged in the aftermath of Cold War geopolitics. As Matthew Sparke has remarked, Luttwak's argument was essentially still realist, historicist, and state-centric (Sparke 2007: 339).

More recently, and probably much because of the rise of major new economic powers, such as China, India and Brazil, there is renewed interest in the concept. Yet, an overview of the literature in recent years indicates that there seems to be no agreement on what exactly the term means. Indeed, it is striking how many articles have been produced that mention the term in the title of the article, without ever clearly defining it. This special issue tackles the many ways in which scholars understand the term geoeconomics, by focusing on a set of major regional powers (China, the EU and Russia) and on how we might understand the actions of these powers in various contexts where economic interests, political power and geography intersect.

When looking at global power from a traditional geopolitical perspective, the world still looks doggedly unipolar, with the US as the undisputed hegemon on the basis of its military power with global reach. However, by donning geoeconomic lenses, the picture looks altogether different. While the transforming global economy is both sustained by and continues to underpin US power, arguably, US dominance has been in long-term relative decline and the constellation of global power is increasingly multipolar. From a realist geopolitical perspective, we would also expect rising powers, such as China, Brazil and India, to start balancing militarily against the United States. Yet, aside from Russia, and despite China's rapid military modernization, there is still limited evidence to 
point towards classical military balance-of-power behaviour among the emerging Great Powers and all have eschewed joining rigid Cold War-style security alliances. ${ }^{1}$

For the emerging powers, we are more likely to observe efforts towards what recent discussions have called "soft balancing"2, i.e. through economic methods-something a geoeconomic perspective is better able to detect. Generally, as Hurrell (2006: 16) has pointed out, the imperatives of economic development are starkly evident in the foreign policies of the BRIC countries, "both in their relative salience within overall government policy and in the importance of specific objectives-the importance of raw materials and energy in Chinese foreign policy; Brazil's desire to diversify export markets; the importance of increasing US and western foreign investment in India; or the role of energy exports as one of the most crucial bargaining tool within Russian foreign policy". Indeed, the geoeconomic drivers in the foreign policies of the BRICS countries and in their mutual cooperation seem clear. In many ways, geoeconomics seems to have risen to rival geopolitics as a strategic desideratum in the foreign policy of these regional powers and the means by which they go about asserting their national interests (e.g. Baracuhy 2013; Hsiung 2009; Khandekar 2014; Tsygankov 2008).

A crucial question concerns to what extent this relative decline of military concerns and rise of economic security concerns in relations between Great Powers is redefining the classical balance of power concept. Balance-of-power considerations were close also to MacKinder's geopolitical thinking (MacKinder 1904: 436). In the early $21^{\text {st }}$ century, the focus on territorial expansion and military build-up is not as overt as it was in MacKinder's time. However, recent developments in Ukraine and elsewhere have resulted in increased attention to the relationship between geoeconomic power and territorial conflicts in international relations. In fact, the "weapons of choice" in countering Russian territorial expansion in Crimea have so far been economic and financial sanctions. Only belatedly, and with great reluctance, have Western governments also taken cautious military steps in response to perceived heightened traditional security threats. Analysts speak of a changed logic of international relations and how competition and rivalry are returning to the international system after a long period of co-operation (Bremmer 2012; Rachman 2010). They predict an era of intensified conflict, though not in military, but rather in economic terms, perhaps enmeshing with novel forms and tools of political power, such as cyber-espionage and smart

\footnotetext{
${ }^{1}$ It may be noted that China and Russia have lately talked up their security cooperation and increased joint military exercises. Nevertheless, mutual historical suspicions still run high and the Chinese, in particular, reject any suggestions of them forming formal military alliances.

${ }^{2}$ For a discussion, see Hurrell (2006).
} 
sanctions. These economic battles are already played out in global fora such as the WTO, the IMF, the World Bank and the G20, in which major powers have found it increasingly difficult to agree over international trade and monetary policy. As a consequence, protectionism has been on the rise (Evenett 2014).

Ikenberry's influential argument in support of the staying-power of the liberal world orderalthough in an updated version, "liberalism 3.0"-postulates that countries such as China must accept certain structural aspects of a (neo)liberal world, as their wealth and prosperity (and thus socio-political stability and power) relies on access to and utilization of global markets, e.g. global access to raw materials and other resources and Western end-markets for exports. Is China then likely to continue to support the updated liberal world order, as long as it is granted new rights and an enhanced position within this order? Ikenberry suggest such a "new deal" is within reach, as it is hard to see that China could detach from global economic flows altogether, let alone establish its own system (Ikenberry 2009). Recent developments-both with regard to Russia, with its sanctions and countersanctions spiral, and increasing autarkic tendencies, as well as China putting much more emphasis in building alternative multilateral economic institutions, such as the Asian Infrastructure Investment Bank (AIIB) and the New Development Bank (NDB)-hang major question marks over Ikenberry's optimistic scenario for the liberal world order.

The emergence of new economic powers, such as China, Brazil and India, that are not following the usual menu of market-oriented policies, but instead often resort to a broad package of neo-mercantilist policies, pose a direct challenge to the liberal ideas and international assumptions that have governed international relations in the aftermath of the Cold War (Bremmer 2012). Meanwhile, accusations of industrial espionage, currency manipulations and protectionism have recently pitted the United States, the European Union, Russia, China, Brazil and other large economies against one another. Together, these developments seem to denote a newfound economy-oriented notion of foreign policy Realism that understands the global political economy in terms of a zero-sum competition in which one side's gain is another's relative loss (Szabo 2014). Some observers even speak of a new geoeconomic game, where economic power is levered aggressively to extract concessions and pressure neighbouring countries (Zarate 2012). Tensions over resource access (energy, food, and water) also appear to be on the rise, fuelled by rapid demand growth from the emerging economies and accelerated environmental degradation (Lee et al. 2012). Such intensified resource stress is said to be propelling economic security to the centre of the global agenda for the foreseeable future and, thus, for geoeconomic calculations to become 
paramount in the concerns of regional powers in their policy calculus (Carmody and Owusu 2007; Zarate 2012).

Yet, despite increasing references to geoeconomics in recent policy analyses, little systematic academic work on contemporary international relations has been undertaken from a geoeconomic perspective. IR-oriented geoeconomic theorising is still in its infant stage and much empirical work needs to be done so as to kick it forward. Few articles dealing with geoeconomics actually provide a clear definition of the term. A review of recent literature shows that geoeconomics tends to be either juxtaposed with geopolitics, in which case they are seen to offer alternatives to each other (Sparke 1998 and 2007; Mudiam 2007; Cowen and Smith 2009; Rozov 2012; Moisio and Paasi 2013), or then the two terms are discussed together without much distinction, as if they were just two sides of the same phenomenon (Couloumbis 2003; Scott 2008 and 2013; Mensah 2010; Morrissey 2011; Lin and Grundy-Warr 2012; Grosse 2014). The former position is theoretically more interesting, as it expends more effort in making a clear distinction between geopolitics and geoeconomics.

The recent discussion on geoeconomics broadly falls into three theoretical approaches. Firstly, one can identify a group of scholars, who discuss geoeconomics as a form of statecraft, whether economic, financial, energy or something else (Stulberg 2005; Youngs 2011; Wu and Koh 2014). ${ }^{3}$ For this group, one of the more useful descriptions of the term has been provided by Richard Youngs. According to Youngs, geoeconomics is broadly understood to revolve around "the use of statecraft for economic ends; a focus on relative economic gain and power; a concern with gaining control of resources; the enmeshing of state and business sectors; and the primacy of economic over other forms of security" (Youngs 2011: 14). The view is state-centric, essentialist, and rooted in (neo)mercantilist theory in that it focuses on states as agents of economic power. Scholars writing in this tradition have, for example, been looking at how Russia uses its energy power as aggressive leverage to further its broader geostrategic interests; how China uses its financial power to gain both political influence and access to strategic raw materials; and how Germany has been using its trading power as geoeconomic leverage for imposing its preferences within the EU (Stulberg 2005; Carmody and Owusu 2007; Mensah 2010; Kudnani 2011; Szabo 2014; Wu and Koh 2014; Mattlin and Nojonen 2015). For these scholars, geoeconomics thus emerges as an economically oriented

\footnotetext{
${ }^{3}$ One rather specific understanding of geoeconomics equates it with the rise of financial power as a determinant of foreign policy success (Wu and Koh 2014: 782). Another one links the term of energy statecraft and leverage (Stulberg 2005: 3).
} 
geopolitics, a form of neo-mercantilism in which "states will tend to act geo-economically simply because of what they are: territorially defined entities designed precisely to out do each other on the world scene" (Luttwak 1993: 64).

Secondly, there is the economic geography approach, where the term refers to the economic aspects of geographical space (Aaltola et al. 2014a; Scholvin and Malamud 2014). This approach is closest to the traditional view of the relationship between politics and geography, as seen in the early writings on geopolitics by MackKinder and Mahan, as well as their later European peers, such Friedrich Ratzel, Rudolf Kjellén or Klaus Haushofer (Pursiainen and Forsberg 2015, 97-105). In other words, this approach is closely related to the more traditional academic disciplines of political and economic geography that study the effects of geographic features on the organisation of politics or the economy.

In this vein, Scholvin and Malamud (2014), show how the economic geography of South America-including weak economic complementarities amongst the countries in the region, insufficient regional infrastructure and physical barriers inherent in the geography making economic integration costly-limits Brazil's sphere of influence in the region. Others have looked at how the new geography of global flows penetrating sovereign state space is rendering traditional geopolitical paradigms of power and security increasingly obsolete (Aaltola et al. 2014a). The dependency of many societies on the fluid global circulation of resources, goods, data, people and finance have increased, bringing into sharper relief a heightened concern with access, or lack thereof, to global flows as a crucial measure of contemporary international power. At the very least, there has been an increased awareness of economic "flow security" and the need for a geoeconomic approach to manage these global flows, securing access to positive ones, while guarding against the negative, illicit ones (Brattberg and Hamilton 2014).

From a more critical constructivist perspective, Cowen and Smith (2009) see a close connection between political space and conceptual understandings of it. They focus on how the new global economic flows recast citizenship and social forms, providing for an emerging "geoeconomic social" in which territorial security is reframed to accommodate these transnational flows, recast security in economic terms, and reframe the state as a geoeconomic agent that seeks to accumulate wealth through market control rather than through acquisition and control of territory. They especially refer to how US dominance through the global marketplace and the Bretton Woods institutions provide "a new disciplining architecture" for financial and ideological policing, replacing the older geopolitical mechanisms of colonial administration. 
Cowen and Smith fall within the critical geography camp, which regards geography as discursive practices that offer possibilities for imagining and re-imagining geographical space (Cowen and Smith 2009; Sparke 1998; Sparke 2007; Moisio and Paasi 2013; Morrissey 2011; Domosh 2013; Aaltola et al 2014b). These scholars thus look at how geoeconomics operates as discourses, shaping and reproducing the worldviews of security strategists and foreign policymakers, and how it thus becomes entrenched in state practice. For most of these critical geographers, the geoeconomic discourse masks neoliberal restructuring and securitization projects, a way to re-stabilise and reproduce the US-led global hegemonic system in a globalised age. The perspective draws from the analytical example of "critical geopolitics"; not taking geoeconomic claims at face value, but rather seeing them "as representational power moves which, notwithstanding their discursive inventiveness, can still have powerful real world effects" (Sparke and Lawson 2003, p. 316). In Mona Domosh's words "the term geoeconomics does not describe a situation; rather, it conjures up a range of meanings, cultures, and places through which description can happen. Geoeconomics, in other words, does not refer simply to a description of economic spatial strategies but instead encompasses a way of seeing the world in which those strategies come to be seen as plausible and desirable." Domosh further argues "By examining geoeconomics as a discursive field, I interrogate the ways in which economic spatial expansion, and the often deleterious effects of this expansion, came to be seen as natural and good by situating that expansion within the context of a particular way of imagining the world." (Domosh 2013: 945)

This special issue contributes to this emerging debate on geoeconomics in international relations and foreign policy analysis. The questions addressed, in short, are how geoeconomics manifests itself and what forms it takes in today's world, which increasingly seems to show some resemblance to the era when Mahan and MacKinder published their seminal writings. Today, as then, we see indications of a scramble to secure scarce natural resources; the merging of strategic and economic power pursuits; and a newfound interest in projecting politico-military influence over distinct geographic areas, or even beyond traditional geographical space into the world of global economic flows-China's intensive island-constructing efforts in the South-China Sea being a topical example. If, indeed, we have entered an Age of Geoeconomics, developing a better theoretical as well as empirical understanding of geoeconomic power and its uses by major actors such as China, India, Japan and Russia, is imperative. So far, surprisingly little solid academic analysis has been undertaken with regard to the geoeconomic activities of these prominent powers in world politics. 
The articles in the special issue collectively strive towards such an improved understanding, not only by investigating the different meanings that geoeconomics as a concept are provided, but also by analysing some of the geoeconomic policies, strategies and means that regional powers deploy in pursuing their strategic objectives on the regional and global scenes.

Mikael Wigell kicks off the special issue with an article that conceptualises regional powers' geoeconomic strategies. Defining geoeconomics as the geostrategic use of economic power, he constructs a typology employing two dimensions: strategic frame (either competitive or cooperative) and economic power (as goal or means). Through this typology, he identifies four idealtypes of geoeconomic strategies: neo-mercantilism, liberal-institutionalism, neo-imperialism and hegemony. Of these four strategies, neo-mercantilist and neo-imperialist strategies derive from a competitive strategic frame that treats foreign relations essentially as zero-sum, i.e., economic power is deployed as leverage in order to extract concessions from other countries, or to exert pressure on them. In contrast, the other two strategies emphasise mutual gains and benefits. Wigell's article, while being conceptual in nature, essentially approximates the conception of geoeconomics as a form of statecraft. The article systematically draws out the dimensions of various forms of geoeconomics as statecraft, and therefore provides a canvas for the rest of the articles in the special issue.

Mikko Huotari and Sandra Heep discuss China's experimental financial and monetary initiatives. In contrast to the dominant power-political interpretation of China's actions in the sphere of international finance, Huotari and Heep provide a compelling argument that China's actions can be explained in light of its domestic concerns, in particular, the path of development that China's capitalism has taken. More than any quest for future dominance of international finance, China's initiatives can be regarded as directed at managing the economic and political risks of China's increasingly deep engagement with global financial flows. The authors do not dispute that China seeks to shape broader global financial structures and flows, but regard this is more as a risk-averse strategy, than as an aggressive zero-sum foreign policy. With this view of geoeconomics, Huotari and Heep fall somewhere in-between the economic geography and economic statecraft schools.

Jonathan Holslag's article is in some ways similar to the previous one. Holslag also deals with China's global economic interactions; although in this case its trade policies rather than its financial and monetary intiatives. Like the previous paper, Holslag draws attention to the domestic origins of China's policies, in particular, pervasive concerns with maintaining economic security, competitiveness and independence. Where he differs from Huotari and Heep is that he adheres 
more to the view that regards China's economic foreign policies through the lens of economic statecraft in general and a neomercantilistic strategy in particular. Thus, whereas Huotari and Heep see China's shaping of financial flows and structures mainly as a defensive move, Holslag regards China's numerous trade policy measures (export credits, trade agreements, tax rebates etc), as aimed at bending global trade flows to its own relative advantage. The difference between their arguments can be described using Wolfers' classical distinction between "milieu goals" and "possession goals" (Wolfers 1962, 73).

Annina Kärkkäinen's article squarely contributes to the debate about geoeconomics as a form of statecraft. It addresses the issue of the importance of natural resources in China's foreign policy strategy and looks at the way the Chinese party-state uses state-owned enterprises to carry it out. More than just discussing the importance of geoeconomics as a strategy for conducting China's external relations, the article uses the case of Zimbabwe to zoom in on the actual means whereby that strategy is being implemented. Interestingly, it finds that the variety of corporate actors involved hinders the process of policy implementation. So far, the debate has largely revolved around the relative importance of geoeconomics as a strategy for realising regional powers' national interests with some observers suggesting that geoeconomics has started to eclipse geopolitics in their strategic thinking. There has been much less focus on the ability of regional powers to actually carry out a geoeconomic strategy and what may possibly complicate the process of implementation. Kärkkäinen's article shows how implementing a geoeconomic strategy is far from straightforward, even for a state like China that is often viewed as an efficient strategic actor. It suggests that wielding geoeconomic power may sometimes be more complicated than wielding geopolitical power, because the intermediate actors needed as geoeconomic "means" are hard to control and get to pull in the same direction. Corporate actors, even state-controlled ones, usually have a different set of interests and sense of loyalty towards the state than e.g. intelligence and military actors.

Mikkola and Käpylä's article approaches the Arctic region from an economic geography perspective. It analyses the drivers and constraints of Arctic economic development, inferring to what extent the Arctic can be expected to transform into a globally important geoeconomic space. The article shows how both geographical challenges of an economic nature, as well as external geopolitical dynamics may come to hinder the realisation of the geoeconomic potential of the Arctic. The case analysis also suggests two issues of broader theoretical interest that should be further explored in other contextual settings. First, against often-held expectations in geoeconomics research, the geoeconomic potential of the Arctic seems to have induced co-operation rather than 
competition. As the realisation of that potential hinge on co-operation to a large degree, the Arctic stakeholders have for the most part refrained from competition and been careful to avoid the sort of conflicts that could come to jeopardise the economic development. However, as a result of the crisis in Ukraine-and this is the second issue-external geopolitical dynamics have started to affect the various forms of co-operation in the region, negatively impacting the prospects of realising the Arctic's geoeconomic potential. As indicated above, much recent literature tends to view geoeconomics as just a sub-variant of geopolitics, as if they were two sides of the same phenomenon. The Arctic case, however, demonstrates how there can be considerable tension between the two, calling for a more nuanced understanding of how geopolitics and geoeconomics may affect each other. Herein, Mikkola and Käpylä's article also points toward a potential flaw with an economic geography approach that fails to take into consideration global geopolitical dynamics and how they affect regional geoeconomic dynamics.

Aalto and Forsberg in their article depart from an economic geography perspective in which Russia's political power and ability to constitute itself as an autonomous actor is seen as being shaped by its key natural resources and the associated financial and institutional features of its geoeconomy. By analysing how the economic sanctions imposed by the EU, the US and other states following the Ukraine crisis in 2014 affects Russia's geo-economy, they show the extent to which Russia's capacity to exercise statecraft is highly susceptible to the structures of the global geoeconomy. As such, their analysis points to some of the linkages between geography and statecraft, and the way they constitute each other. It further suggests how a more eclectic approach, combining the different theoretical lenses and elements discussed above, could prove a fruitful avenue for geoeconomics analysis.

In sum, these articles have provided a set of perspectives on the concept of geoeconomics that fall more within the geoeconomics as a form of statecraft or as economic geography perspectives, less so the critical geography view. However, economics itself is a contested term that carries different connotations to different people. Economics can variously be taken to mean, e.g. balancing of income and expenses (the classical political economy view), anything involving calculative behaviour (mainstream economic sociology), or just about anything that has been labelled economics (the performative aspects of economics). In deepening our understanding of geoeconomics, we need to probe more deeply into the interconnections between space, politics and economics. 


\section{References}

Aaltola M, Käpylä J, Mikkola H, Behr T (2014a) Towards the geopolitics of flows: Implications for Finland. FIIA Report 40. The Finnish Institute of International Affairs, Helsinki

Aaltola M, Käpylä J, Vuorisalo V (2014b) The Challenge of Global Commons and Flows for US Power: The Perils of Missing the Human Domain. Farnham: Ashgate

Baracuhy B (2013) Brazilian economic diplomacy: Agriculture and the WTO. In Bayne, N, Woolcock, $S$ (eds) The New Economic Diplomacy: Decision-making and Negotiation in International Economic Relations, Ashgate Publishing, Aldershot, pp 341-357

Brattberg E, Hamilton DS (eds) (2014) Global flow security: A new security agenda for the transatlantic community in 2030. Washington DC: Center for Transatlantic Relations

Bremmer I (2012) Every Nation for Itself: Winners and Losers in a G-Zero World. London: Penguin Books

Carmody PR, Owusu FY (2007) Competing hegemons? Chinese versus American geo-economic strategies in Africa. Political Geography 26:504-524

Cosgrove DE (2008) Geography and Vision: Seeing, Imagining, representing the World. London: I.B.Tauris \& Co.

Couloumbis T (2003) Toward a global geopolitical and geoeconomic concert of powers?, Southeast European and Black Sea Studies 3(3):17-27

Cowen D and Smith N (2009) After geopolitics? From the geopolitical social to geoeconomics, Antipode 41(1):22-48

Domosh M (2013) Geoeconomic imaginations and economic geography in the early twentieth century, Annals of the Association of American Geographers 103(4):944-966

Evenett SJ (2014) The Global Trade Disorder: The $16^{\text {th }}$ GTA Report. London: CEPR Press

Grosse TG (2014) Geoeconomic relations between the EU and China: The Lessons From the EU Weapon Embargo and From Galileo, Geopolitics 19(1):40-65

Hsiung JC (2009) The age of geoeconomics, China's global role, and prospects of cross-strait integration. Journal of Chinese Political Science 14:113-133

Hurrell A (2006) Hegemony, liberalism and global order: what space for would-be great powers?, Int Aff 82(1):1-19

Ikenberry, J (2009) Liberal internationalism 3.0: America and the dilemmas of liberal world order, Perspectives on Politics 7(1):71-87

Khandekar G (2014) Modi's foreign policy mantra: Geoeconomics, regional hegemony, global aspirations. Agora Asia-Europe 17. FRIDE, Madrid

Kudnani H (2011) Germany as a geo-economic power. The Washington Quarterly 34(3):31-45

Lee B et al. (2012) Resources Futures: A Chatham House Report. London: The Royal Institute of International Affairs

Lin S and Grundy-Warr C (2012) One Bridge, Two Towns and Three Countries: Anticipatory Geopolitics in the Greater Mekong Region, Geopolitics 17:952-979 
Luttwak EN (1990) From geopolitics to geo-economics: logic of conflict, grammar of commerce, The National Interest 20:17-24

Luttwak EN (1993) The coming global war for economic power: There are no nice guys on the battlefield of geoeconomics. The International Economy 7/5:18-67

MacKinder H (1904) The Geographical Pivot of History. The Geographical Journal 23(4):421-437

Mahan AT (1890) The Influence of Seapower on History: 1660-1783. Boston: Little, Brown and Co.

Mattlin $\mathrm{M}$ and Nojonen M (2015) Conditionality and path dependence in Chinese lending, Journal of Contemporary China 24(94)

Mensah C (2010) China's foray into Africa: Ideational underpinnings and geoeconomic interests, African Journal of Political Science and International Relations 4(3):96-108

Moisio S and Paasi A (2013) From Geopolitical to Geoeconomic? The Changing Political Rationalities of State Space, Geopolitics 18(2):267-283

Morrissey J (2011) Closing the Neoliberal Gap: Risk and Regulation in the Long War of Securitization, Antipode 43(3):874-900

Mudiam PR (2007) Indian Power Projection in the Greater Middle East: Tools and Objectives, Perspectives on Global Development and Technology 6:417-439

Pursiainen, C and Forsberg, T (2015) Ulkopolitiikkaa norsunluutornista. Tampere: Chan Puma House Rachman G (2010) Zero-Sum World: Politics, Power and Prosperity after the Crash. London: Atlantic Books

Rozov NS (2012) Geopolitics, Geoeconomics, and Geoculture: The Interrelation of Dynamic Spheres in the History of Russian Sociological Research 51(4):67-90

Scholvin S, Malamud A (2014) Is there a geoeconomic node in South America? Geography, politics and Brazil's role in regional economic integration. ICS working papers no. 2.

www.ics.ul.pt/publicacoes/workingpapers/wp2014/wp2014_2.pdf. Accessed 4 December 2014

Scott D (2008) The Great Power 'Great Game' between India and China: 'The Logic of Geography', Geopolitics 13(1):1-26

Scott D (2013) India's Role in the South China Sea: Geopolitics and Geoeconomics in Play, India Review 12(2):51-69

Sparke M (1998) From geopolitics to geoeconomics: Transnational state effects in the borderlands, Geopolitics 3(2):62-98

Sparke M (2007) Geopolitical Fears, Geoeconomic Hopes, and the Responsibilities of Geography, Annals of the Association of American Geographers 97(2):338-349

Stulberg AN (2005) Moving Beyond the Great Game: The Geoeconomics of Russia's Influence in the Caspian Energy Bonanza, Geopolitics, 10(1):1-25

Szabo SF (2014) Germany's commercial realism and the Russia problem. Survival 56(5):117-128

Tsygankov AJ (2007) The return to Eurasia: Russia's identity and geoeconomic choices in the postSoviet world, in Helleiner E, Pickel A (eds) Economic nationalism in a globalizing world. New York, Cornell University Press

Wolfers, A (1962) Discord and Collaboration. Baltimore: The Johns Hopkins University Press 
Wu F and Koh DW (2014) From Financial Assets to Financial Statecraft: The case of China and emerging economies of Africa and Latin America, Journal of Contemporary China 23(89):781-803 Youngs R (2011) Geo-economic futures. In: Martiningui, A and Youngs, R (eds), Challenges for European Foreign Policy in 2012: What Kind of Geo-Economic Europe? Madrid: FRIDE

Zarate J (2012) Playing a New Geoeconomic Game. In: Cohen C, Gabel J (eds), 2012 Global Forecast: Risk, Opportunity and the Next Administration. Washington, DC: Center for Strategic and International Studies 